\title{
EVALUATION OF ANAEROBICALLY DIGESTED BIOMASS IN CATALYTIC SUPERCRITICAL WATER GASIFICATION FOR BIOFUEL PRODUCTION
}

\section{Tülay GÜNGÖREN MADENOĞLU *}

\author{
Department of Chemical Engineering, Engineering Faculty, Ege University, İzmir, Turkey
}

\begin{abstract}
Digested water hyacinth with waste sludge as inoculum were obtained after anaerobic digestion at 35 and $45^{\circ} \mathrm{C}$. High organic content of digested biomass were evaluated through gasification at supercritical conditions of water in the absence and presence of catalysts $\left(\mathrm{KOH}, \mathrm{NaOH}, \mathrm{LiOH}\right.$ and $\left.\mathrm{K}_{2} \mathrm{CO}_{3}\right)$ with 10 wt.\% of volatile solid in feed. Supercritical water gasification of digested biomass was performed in batch reactor system at temperature and pressure ranges of $500-600^{\circ} \mathrm{C}$ and $35-45$ $\mathrm{MPa}$, respectively. The highest carbon gasification efficiency, hydrogen and methane yields were reached at $600^{\circ} \mathrm{C}$ (with samples digested at $45^{\circ} \mathrm{C}$ ) in the absence of catalyst as 84.6 ( $\mathrm{g} \mathrm{C}$ in gaseous/g C in digestate), $53.0\left(\mathrm{~mol} \mathrm{H}_{2} \%\right.$ ) and 14.2 (mol $\mathrm{CH}_{4} \%$ ), respectively. High organic content of digested biomass was converted by supercritical water gasification to methane and hydrogen rich gas, and aqueous products (aliphatic hydrocarbons, phenol, substituted phenols, N-heterocyclic, substituted N-heterocyclics, and substituted benzene) that can be evaluated as platform chemicals.
\end{abstract}

Keywords: Water hyacinth, Supercritical water gasification, Hydrogen, Methane

\section{INTRODUCTION}

Water hyacinth is an aquatic weed that spreads very rapidly and cause environmental problems for irrigation, navigation, aquatic life and crops. Utilization of waste plants is essential for energy production. Anaerobic digestion (AD) is a method for biological conversion of organic materials into biogas and digestate. Conversion of the volatile organic matter is between 40-60\% in AD systems and the amount of digestate left is usually around $50 \%$ of the fed material [1]. After AD, digested biomass still has high organic content which was mostly evaluated as natural fertilizer or composting material [2]. The digestates were used as fertilizer due to their suitable contents of $\mathrm{N}, \mathrm{P}, \mathrm{K}$ and micronutrients. However, high variability and unbalanced contents of digestate makes their analysis necessary before they can be used as fertilizer [3]. Evaluation of digestate as fertilizer is not suitable because of low capacity for application in agriculture, different pollutions like heavy metals and organic compounds, danger of infection, legal problems and transportation distances. In addition, composting process produces mostly carbon dioxide which is not valuable for energy production and increase greenhouse gas emissions.

Digestate with high organic content can be converted to hydrogen and methane rich gas by supercritical water gasification (SCWG). The most important advantages of SCWG are gasification of biomass without drying, high reaction rates, formation of less coke and carbon monoxide [4]. AD has been used for many centuries, while SCWG is a much newer and more technologically advanced process. There are some comparisons between the two processes. Simultaneous production of methane and hydrogen rich gas with high yield can be accomplished in SCWG. Former application of AD provides physical consistency of digestate for handling of pumpable fluid that is one of main requirement in SCWG. AD is a biological process whereas SCWG is a thermochemical process. This allows SCWG to be more uniform, precisely controllable, and repeatable in its performance regardless of feedstock. A SCWG system will give higher gas yield than an AD system because the conversion is almost complete. Application of SCWG after AD provides conversion of volatile organic materials up

*Corresponding Author: tulay.madenoglu@ege.edu.tr

Receiving Date: 01 October 2017 Publishing Date: 29 June 2018 
to $99 \%$ which cannot be succeeded by only AD system. Large volume of digestate left after AD was minimized by SCWG into water and inorganics that were almost clean and have no odor. AD systems are low-pressure systems (mostly atmospheric) while SCWG systems operate at a higher pressure (around $20 \mathrm{MPa}$ ) that is useful for gas cleanup processes such as pressure-swing adsorption and membrane separation both require a large pressure differential. Application of SCWG after AD also provides product gas under high pressure which is usually required for gas transfer and storage. Extra compression cost will emerge if AD process was applied alone.

Gas product composition changes with operating conditions and catalyst type used. Metallic, alkali, carbon-based catalysts are usually used in SCWG of biomass to enhance the gas yield and lower coke. While metallic catalysts such as Raney nickel, $\mathrm{Ru} / \mathrm{C}$ and $\mathrm{Ru} / \mathrm{Al}_{2} \mathrm{O}_{3}$ resulted in high methane yields [5], alkali catalysts such as $\mathrm{NaOH}, \mathrm{KOH}, \mathrm{K}_{2} \mathrm{CO}_{3}$ and $\mathrm{Na}_{2} \mathrm{CO}_{3}$ accelerate hydrogen production rate [6-8].

Model compounds such as cellulose [5, 6], hemicellulose [9, 10], lignin [4, 11, 12], pyrocatechol [13], and real biomass feedstocks such as agricultural wastes [14, 15], aquatic weed [16, 17], sewage sludge $[18,19]$ etc. have been gasified in supercritical water. There are only few studies present on supercritical water gasification of digested biomass in anaerobic digestion. Boukis et al. [20] were gasified digested sludge in the pilot plant using a $\mathrm{Ru} / \mathrm{C}$ catalyst protected by a bed of $\mathrm{ZnO}$ to remove sulfur compounds and potassium hydrogen carbonate to catalyze the water-gas shift reaction. They obtained a gas product (CGE of $45.8 \%$ ) with $16 \% \mathrm{H}_{2}$ and $60 \% \mathrm{CH}_{4}$ at $420{ }^{\circ} \mathrm{C}$ and 280 bar. Series application of SCWG with anaerobic digestion was investigated by using zootechnical sludge. This hybrid process was thought as clean technology to produce electricity and biomethane, and also evaluated as treatment of wastewater [21]. Differing from aforementioned studies [20, 21], this study were mostly concentrated on conversion of digestates to hydrogen rich gas not to methane rich gas. Hydrogen is a clean energy carrier, not an energy source and can be used in fuel cells to generate electricity, or power and heat. It also provides reduction in greenhouse gas emissions compared to methane.

Reaction time is another parameter in SCWG process. Sinag et al. [22] was studied the catalytic hydropyrolysis of glucose at $500^{\circ} \mathrm{C}, 30 \mathrm{MPa}$, and $1 \mathrm{~h}$ reaction time in a batch reactor. They found that after a reaction time of $1 \mathrm{~h}$, the system is very close to equilibrium. The researchers [23] found that hydrogen yield increased from 7 to 14 ( $\mathrm{mol} / \mathrm{kg}$ of biomass feeding) when reaction time increased from 10 to 40 minutes during experiments with rice husk at $650^{\circ} \mathrm{C}, 30 \mathrm{MPa}$ and 2 wt $\%$ of biomass concentration in a batch reactor. No further increase was noted when the reaction time increased to 60 minutes. As it is understood from the studies in the literature, the reason why the reaction time is chosen for one hour is the optimum period in which the gas production and the gas composition do not change any more.

In this study, supercritical water gasification of digested water hyacinth with waste sludge (at 35 and $45^{\circ} \mathrm{C}$ ) was investigated in the absence and presence of alkali catalyst $\left(\mathrm{KOH}, \mathrm{NaOH}, \mathrm{LiOH}\right.$ and $\left.\mathrm{K}_{2} \mathrm{CO}_{3}\right)$ at temperature and pressure ranges of $500-600^{\circ} \mathrm{C}$ and $35-45 \mathrm{MPa}$, respectively. Series application of AD with SCWG was used to evaluate high organic content of digested biomass to produce methane and hydrogen rich gas, and aqueous products to use as platform chemicals.

\section{EXPERIMENTAL}

\subsection{Materials}

Potassium hydroxide ( $\mathrm{KOH}$, purity of $\geq 95 \mathrm{wt} \%$ ), sodium hydroxide ( $\mathrm{NaOH}$, purity of $\geq 95 \mathrm{wt} \%$ ), lithium hydroxide_( $\mathrm{LiOH}$, purity of $\geq 98 \mathrm{wt} \%)$ and sodium carbonate $\left(\mathrm{K}_{2} \mathrm{CO}_{3}\right.$, purity of $\left.\geq 95 \mathrm{wt} \%\right)$ were supplied by Merck (St. Louis, MO, USA). Helium, nitrogen, air and hydrogen gases (purity of $\geq 99.9 \%$ ) were purchased from Erma Gaz A.S. (Izmir, Turkey). Distilled and deionized (DDI) water was prepared using a Milli-Q Ultrapure water purification system with a $0.22 \mu \mathrm{m}$ filter (Billerica, MA, USA). 


\subsection{Experimental Procedure}

Anaerobically digested water hyacinths $(50 \mathrm{~g} / \mathrm{L})$ with waste sludge $(50 \mathrm{~g} / \mathrm{L})$ at different temperatures ( 35 and $45^{\circ} \mathrm{C}$ ) were used as feedstock for SCWG studies. Proximate analysis of biomass solution after anaerobic digestion was given in Table 1 . SCWG studies were performed in a batch reactor with a volume of $100 \mathrm{~mL}$. Batch reactor is made of stainless steel (SS316) and constructed to endure $50 \mathrm{MPa}$ at $650^{\circ} \mathrm{C}$. Detailed information on batch reactor system was given in a previous study [24].

Table 1. Proximate analysis of digested biomass solution after anaerobic digestion.

\begin{tabular}{|c|c|c|}
\hline Run Code & D35 & D45 \\
\hline Digestion Temperature $\left({ }^{\circ} \mathbf{C}\right)$ & 35 & 45 \\
\hline Total Solids $(\mathbf{T S}$, wt. \%) & 2.16 & 2.16 \\
\hline Volatile Solids (VS, wt.\%) & 65.9 & 67.2 \\
\hline Total Carbon (TC, wt.\%) & 29.2 & 30.1 \\
\hline
\end{tabular}

In a previous study [25], anaerobic digestion of water hyacinths $(50 \mathrm{~g} / \mathrm{L})$ with waste sludge $(50 \mathrm{~g} / \mathrm{L})$ was performed at different temperatures $\left(35\right.$ and $\left.45^{\circ} \mathrm{C}\right)$. These high organic content digestates were conducted to SCWG after completion of biogas production in anaerobic digestion. Digested biomass solution with a volume of $15 \mathrm{~mL}$ was used in SCWG at 500 and $600^{\circ} \mathrm{C}$ (pressure range of 35-45 MPa). Catalyzed studies were performed with $\mathrm{KOH}, \mathrm{NaOH}, \mathrm{LiOH}$ and $\mathrm{K}_{2} \mathrm{CO}_{3}$ with 10 wt.\% of volatile solid in feed. Experimental conditions for SCWG of digested biomass were given in Table 2.

Table 2. Experimental conditions for SCWG of digested biomass.

\begin{tabular}{|c|c|c|}
\hline Run Code & D35T5/D35T6 & D45T5/D45T6 \\
\hline SCWG Temperature $\left({ }^{\circ} \mathbf{C}\right)$ & $500 / 600$ & $500 / 600$ \\
\hline Volume of feed $(\mathbf{m L})$ & 15 & 15 \\
\hline Mass of TS in feed $(\mathbf{g})$ & 0.325 & 0.323 \\
\hline Mass of VS in feed $(\mathbf{g})$ & 0.214 & 0.217 \\
\hline Mass of catalyst $(\mathbf{g})$ & 0.0214 & 0.0217 \\
\hline
\end{tabular}

Inside of the reactor was purged with nitrogen for $15 \mathrm{~min}$. to obtain oxygen-free medium. Reactor is heated with an electrical heater with a constant heating rate of $6 \mathrm{~K} \mathrm{~min}^{-1}$. Reaction time was selected as one hour that was not including heating period. At the end of reaction time, batch reactor was rapidly cooled down by using fans and then placed in cooled water. The volume of gaseous products was measured by using gasometer and gaseous samples were collected in gas tight syringes and analyzed in gas chromatography. Since all experiments were performed in triplicate, deviation in the volume of gaseous product was calculated as $\pm 10 \%$ by using standard deviation formula. The inside of the reactor was washed with water and then filtered to separate aqueous product and solid residue. Aqueous products were stored in a refrigerator at $4^{\circ} \mathrm{C}$. Detailed explanation on analysis of the gaseous and aqueous products was given in the section 2.3.

\subsection{Analysis}

\subsubsection{Feed Characterization}

Digested biomasses are subjected to analysis of total solids, volatile solids and total carbon contents. The total solids content includes both the suspended solids and dissolved salts, and used to determine dry weight of digested biomass. The volatile solids represent the organic content of the sample and 
total carbon content is the sum of the organic and inorganic carbon present in the sample. The total solids, volatile solids and total carbon contents were determined by methods of ASTM E1756, ASTM E872 and ASTM E777, respectively.

\subsubsection{Gaseous Product Analysis}

Composition of the gaseous products $\left(\mathrm{H}_{2}, \mathrm{CO}_{2}, \mathrm{CO}\right.$ and $\mathrm{C}_{1}-\mathrm{C}_{4}$ hydrocarbons) was analyzed by Agilent HP 7890A gas chromatography (GC) equipped with 3 detectors (FID-TCD-TCD) and serially connected 7 columns. Technical features and operating conditions of gas chromatography were given in previous work [26]. The standard deviation for the results of gas composition was calculated to be $\pm 2 \%$.

\subsubsection{Aqueous Product Analysis}

Total organic carbon (TOC) content of aqueous phase was analyzed by a TOC analyzer (Shimadzu TOC- $\mathrm{V}_{\mathrm{CPH}}$, Japan). Organic compounds in the aqueous phase were isolated by solid-phase extraction (SPE) technique and qualitatively analyzed by GC-MS (Agilent Technologies, HP 7890A-5975 VL MSD). Helium was used as carrier gas with a flowrate of $1.2 \mathrm{ml} / \mathrm{min}$. HP-5MS (30 $\mathrm{m} \times 250 \mu \mathrm{m} \times 0.25$ $\mu \mathrm{m}$ ) column was used and oven program was; $40^{\circ} \mathrm{C}$ for $8.5 \mathrm{~min}$., then $22^{\circ} \mathrm{C} / \mathrm{min}$ to $48^{\circ} \mathrm{C}$ for $5 \mathrm{~min}$., then $5^{\circ} \mathrm{C} / \mathrm{min}$ to $141^{\circ} \mathrm{C}$ for $1 \mathrm{~min}$., and then $5^{\circ} \mathrm{C} / \mathrm{min}$ to $270^{\circ} \mathrm{C}$ for $2 \mathrm{~min}$. Injection, MS source and MS quadrupole temperatures were $260^{\circ} \mathrm{C}, 230^{\circ} \mathrm{C}$ and $150^{\circ} \mathrm{C}$, respectively. Mass spectroscopy library of the National Institute of Standards and Technology (NIST) was used to identify compounds.

\section{RESULTS AND DISCUSSION}

Carbon gasification efficiency ( $\mathrm{g} \mathrm{C}$ in gaseous/g $\mathrm{C}$ in digestate) and carbon liquefaction efficiency ( $\mathrm{g}$ $\mathrm{C}$ in liquid/g $\mathrm{C}$ in digestate) were expressed by using following formulas;

Carbon gasification efficiency: $($ CGE, wt. $\%)=\frac{\sum_{\mathrm{i}} \mathrm{n}_{\mathrm{i}} \mathrm{C}_{\mathrm{iV}} \frac{\mathrm{PV}}{\mathrm{RT}} \mathrm{M}}{\mathrm{wm}} \times 100$

Carbon liquefaction efficiency: (CLE, wt. $\%)=\frac{\mathrm{TOC}_{\mathrm{aq}} \overline{\mathrm{V}}}{\mathrm{wm}} \times 100$

Reactor pressure was stabilized at desired value with a precision of $\pm 0.5 \mathrm{MPa}$. Carbon balance of products (gaseous and aqueous) closed within 57.2-93.6\%. Remaining part in carbon balance was coke, tar and loss. All experiments were performed in triplicate with an approximately $5 \%$ resulting precision of product efficiency.

\subsection{Product Yields}

Variations of product efficiencies (CGE and CLE) with temperature $\left(500\right.$ and $\left.600^{\circ} \mathrm{C}\right)$ were given in the absence and presence of catalyst in Figures 1 and 2 for samples digested at 35 and $45^{\circ} \mathrm{C}$, respectively. CGE considerably increased with increasing temperature while slightly decreased with the addition of alkali catalysts. In general, temperature is the most dominant factor in SCWG. High reaction temperature accelerates free-radical reactions towards formation of low-molecular weight compounds and higher yield of gaseous products [27]. Moreover, alkali catalysts prove high reaction rate and provide high conversion at lower reaction temperatures compared to uncatalyzed ones [28].

When digested water hyacinth at $35^{\circ} \mathrm{C}$ was used in SCWG, the highest CGE (79.2 wt.\%) and lowest CLE (9.8 wt.\%) yields were reached at $600^{\circ} \mathrm{C}$ with $\mathrm{KOH}$. Other catalysts $\left(\mathrm{NaOH}, \mathrm{LiOH}\right.$ and $\left.\mathrm{K}_{2} \mathrm{CO}_{3}\right)$ give lower CGE than uncatalyzed one. Complete conversion to products (that means total of CGE and CLE) was found lower with these aforementioned catalysts (Figures 1 and 2). Addition of alkali catalysts may be caused increased formation of sticky tar products which were not recovered from the inside of reactor wall. 


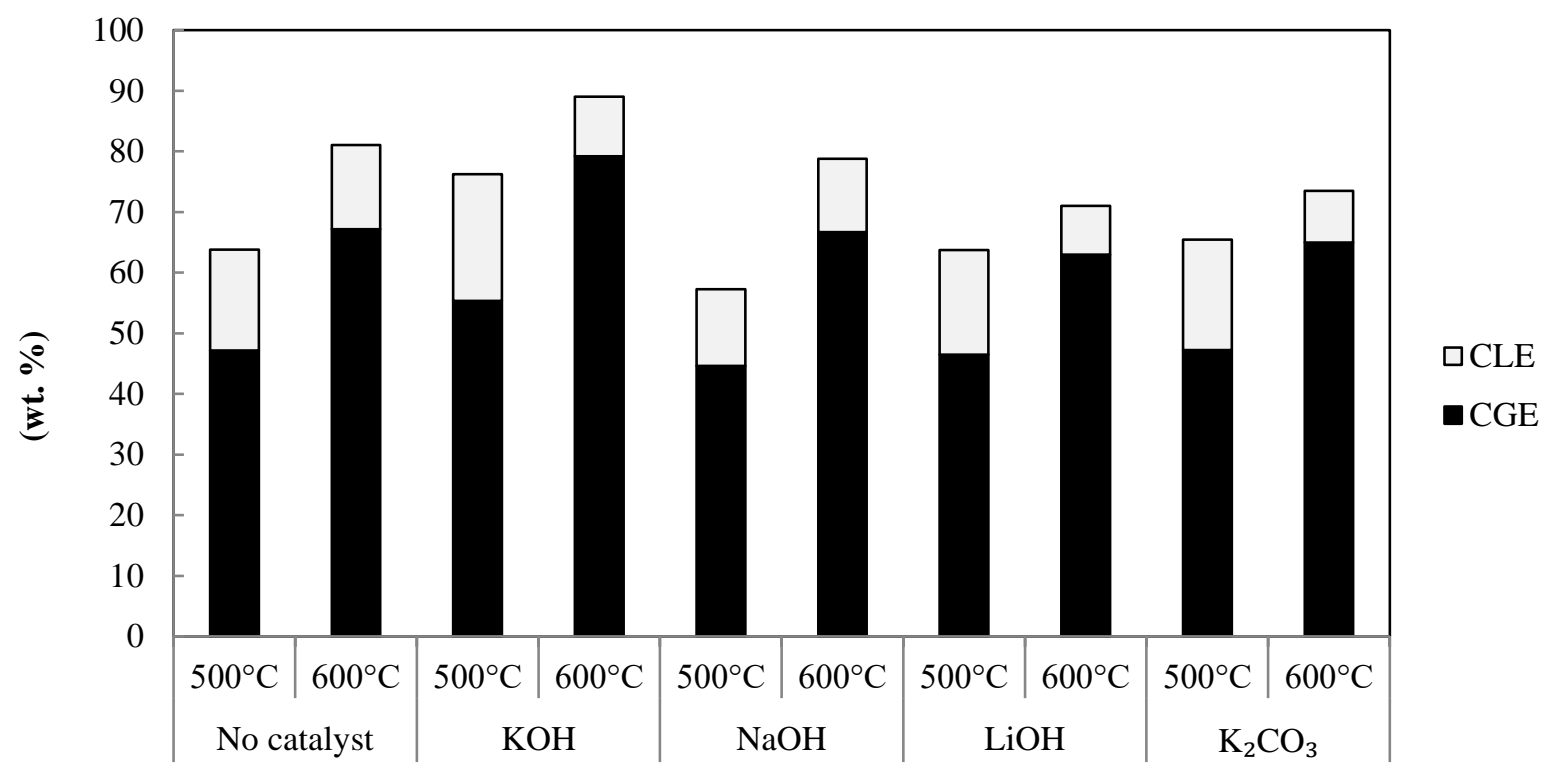

Figure 1. Effects of temperature and alkali catalyst on product yield for SCWG of digested water hyacinth at $35^{\circ} \mathrm{C}$.

When digested water hyacinth at $45^{\circ} \mathrm{C}$ was used in SCWG, the highest CGE (84.6 wt.\%) and lowest CLE (8.4 wt.\%) yields were reached at $600^{\circ} \mathrm{C}$ in the absence of catalyst. Addition of catalysts affects CGE negatively and CLE was improved as the digested biomass converted to intermediates in the aqueous products. Higher CGE and CLE were obtained in SCWG of samples digested at $45^{\circ} \mathrm{C}$ compared to $35^{\circ} \mathrm{C}$. As the biomass samples was better hydrolyzed and degraded into biogas and digestate during anaerobic digestion at $45^{\circ} \mathrm{C}$, SCWG reactions progress more easily with heavily degraded biomass into gaseous and aqueous products (Figure 2).

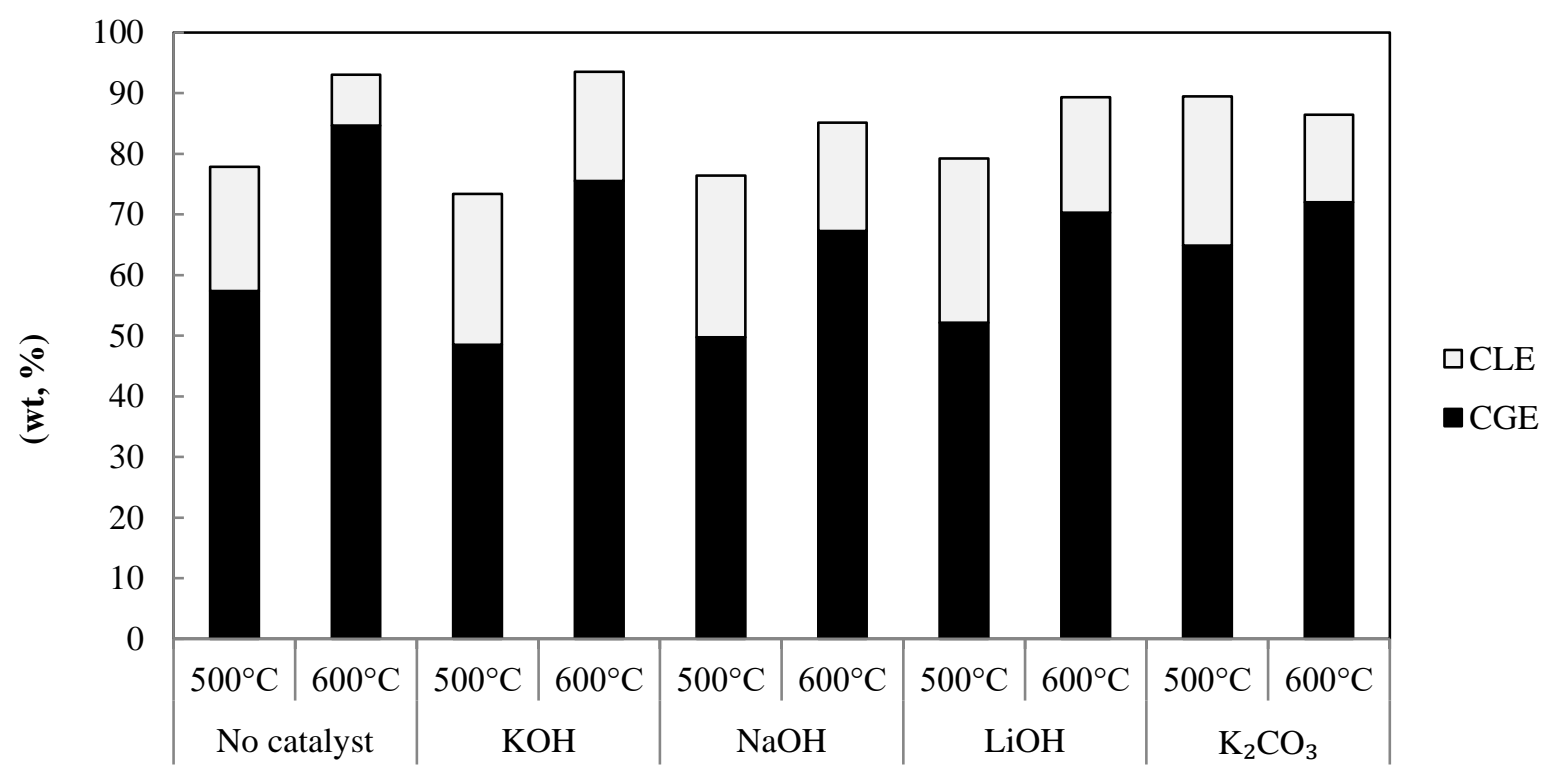

Figure 2. Effects of temperature and alkali catalyst on product yield for SCWG of digested water hyacinth at $45^{\circ} \mathrm{C}$. 


\subsection{Gaseous Products}

Figures 3 and 4 shows the variations of gaseous product composition with temperature in the absence and presence of catalyst for samples digested at 35 and $45^{\circ} \mathrm{C}$, respectively. Gaseous products were mainly composed of $\mathrm{CO}_{2}, \mathrm{H}_{2}, \mathrm{CH}_{4}$, and $\mathrm{C}_{2}-\mathrm{C}_{4}$ hydrocarbons as minors. It is found that gaseous product yield (mol gas $/ \mathrm{kg}$ digestate) increased with increasing SCWG temperature. As the SCWG temperature increased from 500 to $600^{\circ} \mathrm{C}$ in the absence of catalyst, hydrogen yield increased from 6.7 to $11.9 \mathrm{~mol} / \mathrm{kg}$, while mole fraction of hydrogen increased from $39.4 \%$ to $44 \%$ for samples digested at $35^{\circ} \mathrm{C}$. Hydrogen yields were found higher when SCWG was applied for samples digested at $45^{\circ} \mathrm{C}$. Hydrogen yield increased from 8.5 to $22.9 \mathrm{~mol} / \mathrm{kg}$, while mole fraction of hydrogen increased from $39.8 \%$ to $53.0 \%$ for samples digested at $45^{\circ} \mathrm{C}$, as the SCWG temperature increased from 500 to $600^{\circ} \mathrm{C}$ in the absence of catalyst.

When the SCWG temperature increased from 500 to $600^{\circ} \mathrm{C}$ in the absence of catalyst, methane yield increased from 2.6 to $4.5 \mathrm{~mol} / \mathrm{kg}$, while mole fraction of methane increased from $15.5 \%$ to $16.7 \%$ for samples digested at $35^{\circ} \mathrm{C}$. Also, methane yields were found higher when SCWG was applied for samples digested at $45^{\circ} \mathrm{C}$. Methane yield increased from 3.1 to $5.4 \mathrm{~mol} / \mathrm{kg}$, while mole fraction of methane increased from $12.5 \%$ to $14.2 \%$ for samples digested at $45^{\circ} \mathrm{C}$, as the SCWG temperature increased from 500 to $600^{\circ} \mathrm{C}$ in the absence of catalyst.

In terms of total of hydrogen and methane yields, $\mathrm{NaOH}$ was found to be effective at $500^{\circ} \mathrm{C}$ and $\mathrm{KOH}$ was found to be effective at $600^{\circ} \mathrm{C}$ in SCWG of samples digested at $35^{\circ} \mathrm{C}$. For this sample, effectiveness of catalysts at $600^{\circ} \mathrm{C}$ can be ordered as $\mathrm{KOH}>\mathrm{NaOH}>\mathrm{K}_{2} \mathrm{CO}_{3}>\mathrm{LiOH}$. Total yields of hydrogen and methane were found higher in the presence of $\mathrm{K}_{2} \mathrm{CO}_{3}$ at $500^{\circ} \mathrm{C}$ and in the absence of catalyst at $600^{\circ} \mathrm{C}$ in SCWG of samples digested at $45^{\circ} \mathrm{C}$.

Based on results of our previous study dealing with anaerobic digestion of water hyacinth with waste sludge [25], the higher biogas and methane yields were reached at $45^{\circ} \mathrm{C}$ compared to $35^{\circ} \mathrm{C}$. In the first phase of anaerobic digestion, complex biopolymer structure (cellulose, hemicellulose and lignin) of the feed was hydrolyzed into monomers and oligomers. In the next phases, these fractions were converted to methane through acidogenesis, acetogenesis and methanogenesis. These reaction steps occurred with higher extent at $45^{\circ} \mathrm{C}$ (thermophilic condition) than $35^{\circ} \mathrm{C}$ (mesophilic condition) that is why methane yield was high at $45^{\circ} \mathrm{C}$. This means that anaerobic digestion at $45^{\circ} \mathrm{C}$ were better fractionated biomass into intermediates that were further easily converted to $\mathrm{H}_{2}$ and $\mathrm{CH}_{4}$ through SCWG. As the compositions of digested water hyacinth were different at 35 and $45^{\circ} \mathrm{C}$, its degradation product composition and yield were found different after SCWG. In addition, this variation affects the effectiveness of catalysts in SCWG. Digested water hyacinth with waste sludge is a complex mixture of degradation products (intermediates) of cellulose, hemicellulose, lignin etc. that can further undergo hydrolysis, pyrolysis, decomposition, steam forming and polymerization reactions in SCWG [29]. Addition of alkali catalyst increased formation of tars and coke amount at elevated temperatures [30] and resulting in lower gaseous product yield at catalyzed condition. Low gaseous product yield in catalyzed condition directly affects gas product distribution. Even though mole fraction of gaseous products was enhanced, it does not reflect on individual gas yields because gaseous product yields found lower at catalyzed condition. As a surplus, the highest carbon gasification efficiency, hydrogen and methane yields were reached at $600^{\circ} \mathrm{C}$ (with samples digested at $45^{\circ} \mathrm{C}$ ) in the absence of catalyst as 84.6 ( $\mathrm{g} \mathrm{C}$ in gaseous/g $\mathrm{C}$ in digestate), $53.0\left(\mathrm{~mol} \mathrm{H}_{2} \%\right)$ and $14.2\left(\mathrm{~mol} \mathrm{CH}_{4} \%\right)$, respectively. 

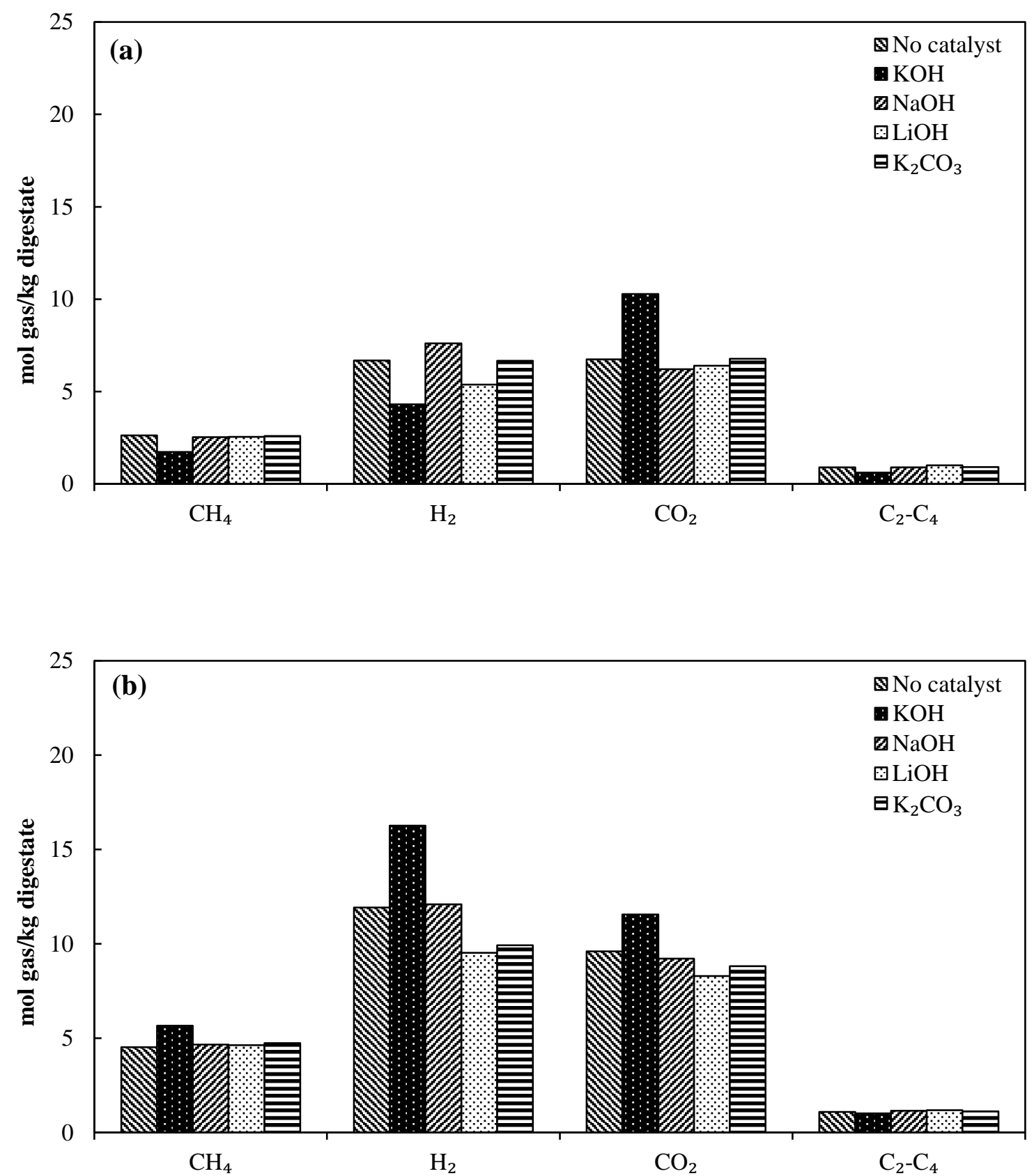

Figure 3. Effect of alkali catalyst on gaseous product composition for SCWG at (a) $500^{\circ} \mathrm{C}$ and (b) $600^{\circ} \mathrm{C}$ of digested water hyacinth at $35^{\circ} \mathrm{C}$.

Total yield of $\mathrm{H}_{2}$ and $\mathrm{CH}_{4}$ was found to be higher than $\mathrm{CO}_{2}$. It is known that presence of alkali salts leads to the formation of formates, which subsequently degrades to hydrogen and carbon dioxide during SCWG [31]. As the mole fraction of CO was found very low in gaseous products, its yield was not given. This situation may be caused by acceleration of water-gas shift reaction and, resulted in decrease in $\mathrm{CO}$ yield and increase in $\mathrm{H}_{2}$ yield. Low yield of $\mathrm{CO}$ also confirms that system reached equilibrium 
after reaction time of one hour. The high yield of hydrogen and methane shows that digested biomass with high organic content can be utilized in SCWG to high energy carriers $\left(\mathrm{H}_{2}\right.$ and $\left.\mathrm{CH}_{4}\right)$.
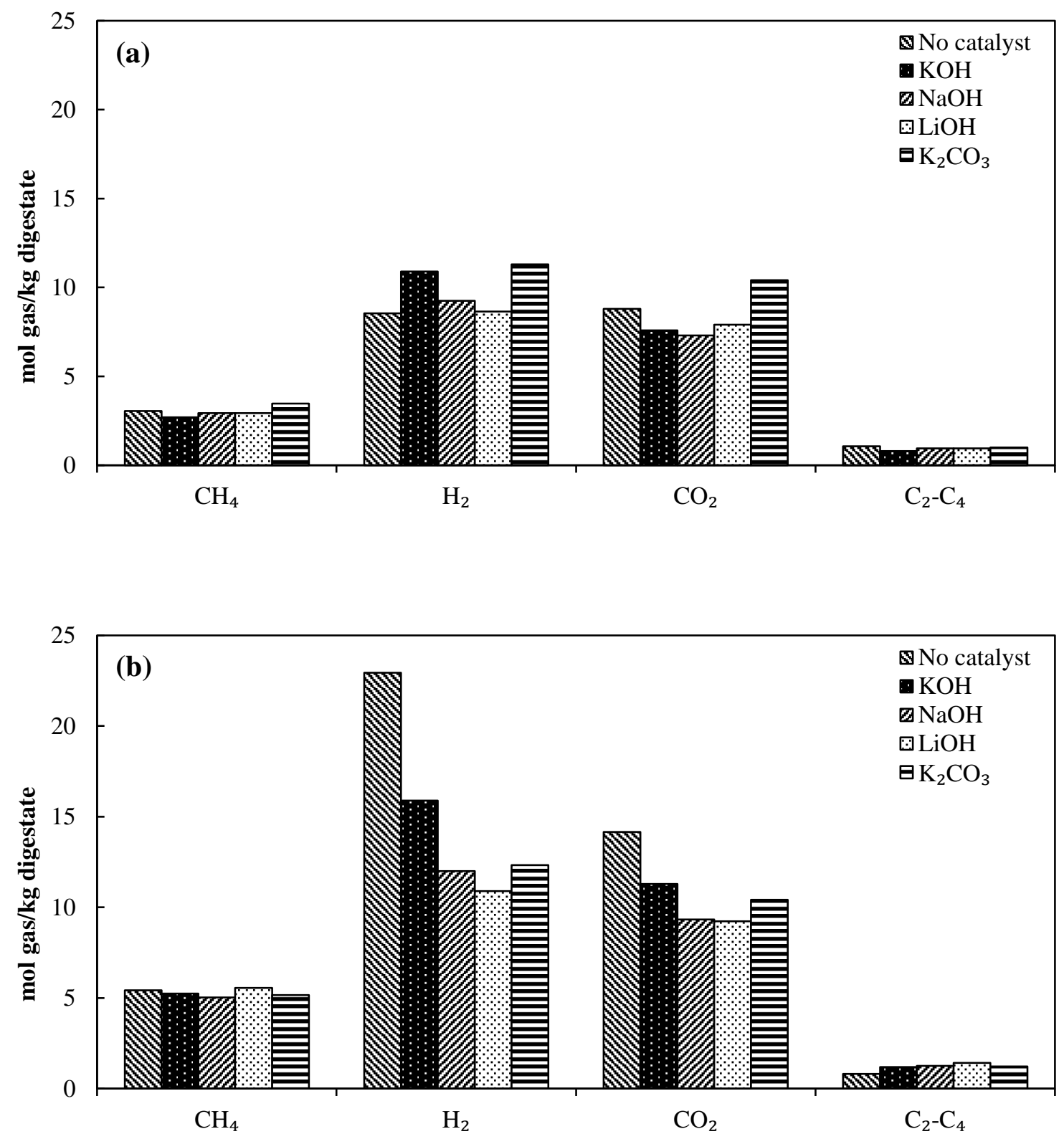

Figure 4. Effect of alkali catalyst on gaseous product composition for SCWG at (a) $500^{\circ} \mathrm{C}$ and (b) $600^{\circ} \mathrm{C}$ of digested water hyacinth at $45^{\circ} \mathrm{C}$.

Table 3 shows CGE and gaseous product composition of different biomasses in SCWG. Hydrogen yield of this study was found higher than these compared studies. Pyrocatechol [13] is a model compound for aromatic compounds in wastewater and lignin in biomass which are both present in digested water hyacinth with waste sludge (from municipal wastewater treatment plant). Cellulose and water hyacinth [32] were gasified in the presence of metal catalyst with high yield of methane. Model compounds are easily degraded in SCW than real biomass feedstock and give high CGE with high $\mathrm{H}_{2}$ 
and $\mathrm{CH}_{4}$ yields. The main component of gaseous product changes depending on the catalyst type. While metallic catalysts give high $\mathrm{CH}_{4}$ yield [20,32], alkali catalysts give high $\mathrm{H}_{2}$ yield [13].

Table 3. Comparison of SCWG results of different biomasses.

\begin{tabular}{|c|c|c|c|c|c|c|c|}
\hline Feedstock & Reactor type & $\mathbf{T}\left({ }^{\circ} \mathbf{C}\right)$ & Catalyst & CGE (\%) & $\begin{array}{c}\mathbf{H}_{\mathbf{2}} \\
(\mathbf{m o l} \%)\end{array}$ & $\begin{array}{c}\mathbf{C H}_{\mathbf{4}} \\
(\mathbf{m o l} \%)\end{array}$ & Reference \\
\hline $\begin{array}{c}\text { Digested water } \\
\text { hyacinth }\end{array}$ & $\begin{array}{c}\text { Batch } \\
\text { autoclave }\end{array}$ & 600 & None & 84.6 & 53.0 & 14.2 & This study \\
\hline Pyrocatechol & $\begin{array}{c}\text { Tumbling } \\
\text { batch }\end{array}$ & 500 & $\mathrm{KOH}$ & n.d. & 52.4 & 9.0 & [13] \\
\hline Pyrocatechol & $\begin{array}{c}\text { Tumbling } \\
\text { batch }\end{array}$ & 500 & $\mathrm{LiOH}$ & n.d. & 40.4 & {$[13]$} \\
\hline Sewage sludge & $\begin{array}{c}\text { Continuous } \\
\text { flow }\end{array}$ & 500 & None & 57.0 & 15.0 & 25.0 & {$[19]$} \\
\hline Sewage sludge & $\begin{array}{c}\text { Continuous } \\
\text { flow }\end{array}$ & 600 & None & 73.0 & 22.0 & 35.0 & {$[19]$} \\
\hline Digestate sludge & $\begin{array}{c}\text { Pilot plant- } \\
\text { continuous }\end{array}$ & 420 & Ru/C & 45.8 & 16.0 & 60.0 & {$[20]$} \\
\hline Cellulose & $\begin{array}{c}\text { Batch } \\
\text { autoclave }\end{array}$ & 400 & Nickel & 97.6 & 3.9 & 43.2 & {$[28]$} \\
\hline Batch & 400 & Nickel & 73.1 & 11.3 & 35.9 & {$[28]$} \\
\hline
\end{tabular}

n.d.: not determined

\subsection{Aqueous Products}

The effects of temperature and alkali catalyst on TOC of aqueous products for SCWG of digested water hyacinth at 35 and $45^{\circ} \mathrm{C}$ were given in Figure 5. Total organic carbon (TOC) is one of the most important parameters in the assessment of the organic pollution in aqueous phase. The TOC removal rate can be defined as the ratio of TOC removed from aqueous products to TOC of fed digested biomass solution. The TOCs of fed digested biomass solutions at 35 and $45^{\circ} \mathrm{C}$ were $14,266.67$ and $14,466.67 \mathrm{mg} / \mathrm{L}$, respectively. The minimum TOC of aqueous products in SCWG (at $600^{\circ} \mathrm{C}$ ) of digested water hyacinth at $35^{\circ} \mathrm{C}$ was found as $149.4 \mathrm{mg} / \mathrm{L}$ in the presence of $\mathrm{LiOH}$. Additionally, the minimum TOC of aqueous products in SCWG (at $600^{\circ} \mathrm{C}$ ) of digested water hyacinth at $45^{\circ} \mathrm{C}$ was found as $126.5 \mathrm{mg} / \mathrm{L}$ in the absence of catalyst. For all runs, TOC removal rate was calculated between $97-98 \%$ for SCWG at $500^{\circ} \mathrm{C}$ and $98-99 \%$ for SCWG at $600^{\circ} \mathrm{C}$. Reduction in TOC of aqueous solution with increasing temperature was in agreement with gaseous product formation.

The organic fraction of aqueous products before (D35/D45) and after (D35T5/D45T5) SCWG were analyzed by GC-MS. As stated by other researchers $[33,34]$, area percentage of each compound was calculated by fraction of total ion chromatogram of each detected compound to total peak area and relative content of the compounds were found qualitatively. Based on GC/MS library search reports, range of the quality for the detected compounds was found between 70-96\%. Compounds were not taken into account when quality was below $70 \%$. 

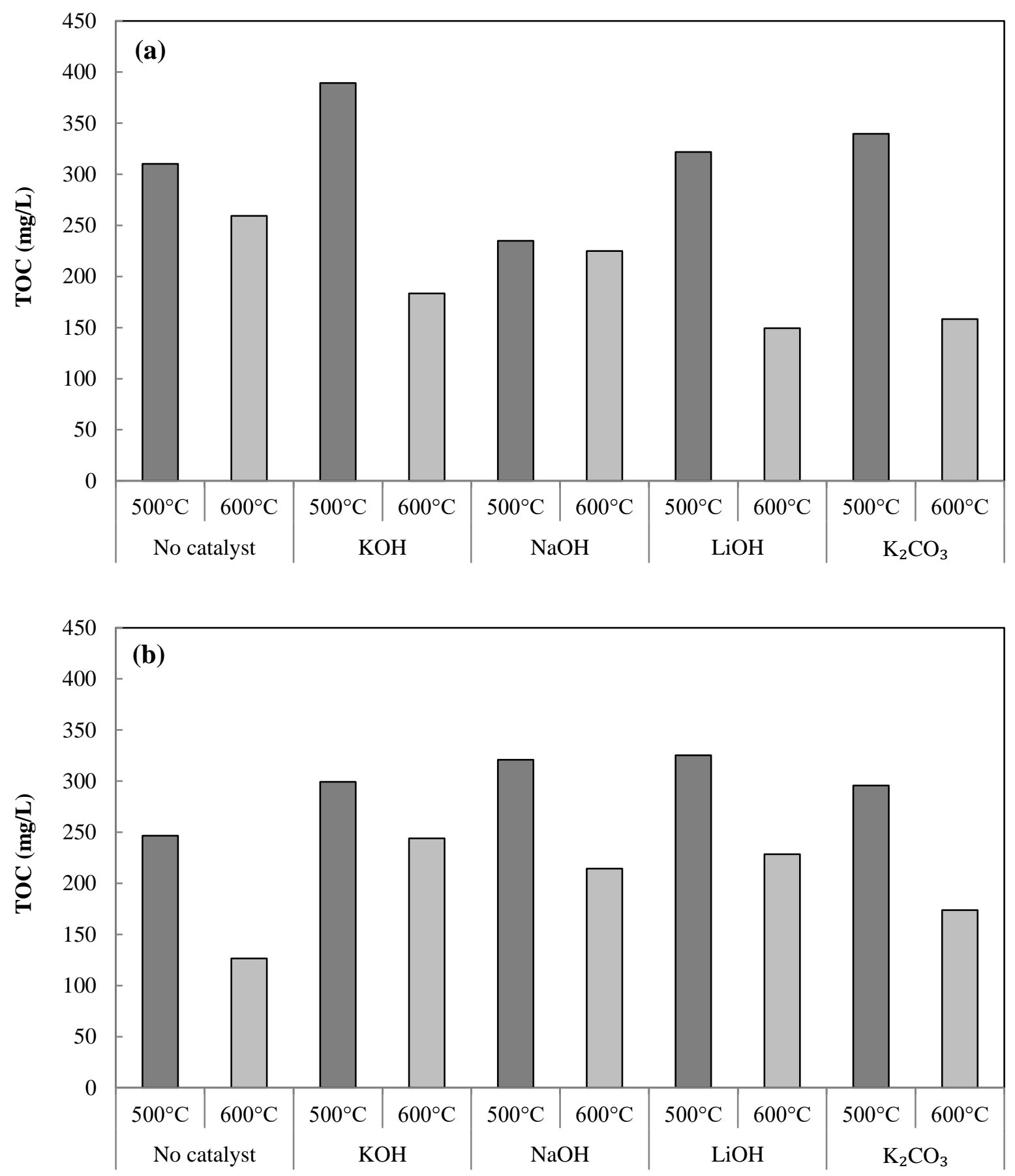

Figure 5. Effects of temperature and alkali catalyst on TOC of aqueous products for SCWG of digested water hyacinth at (a) $35^{\circ} \mathrm{C}$ and (b) $45^{\circ} \mathrm{C}$.

According to GC-MS analysis, organic fraction of aqueous products was identified only at $500^{\circ} \mathrm{C}$, because carbon liquefaction efficiency and total organic content of aqueous products were found lower at $600^{\circ} \mathrm{C}$. As given in Table 4, organic fraction of aqueous products was mainly composed of aliphatic hydrocarbons, phenol, substituted phenols, N-heterocyclic (indole), substituted N-heterocyclics, and substituted benzene (p-xylene) that can be used as platform chemicals for pharmacy, dye industry, pesticide and polymer processes. P-xylene is widely used as a feedstock to produce industrial 
chemicals such as terephthalic acid (TPA), purified terephthalic acid (PTA) and dimethyl-terephthalate (DMT). TPA, PTA and DMT are used to manufacture polyethylene terephthalate (PET) polyesters. Nhexadecane is used as a substrate for the bacterial production of biosurfactants [35].

Table 4. Identification of organic compounds in aqueous product before (D35/D45) and after (D35T5/ D45T5) SCWG of digested biomass.

\begin{tabular}{|c|c|c|c|c|c|c|}
\hline \multirow{2}{*}{ No } & \multirow{2}{*}{ Formula } & \multirow{2}{*}{ Compounds } & \multicolumn{4}{|c|}{ Area Percentage, \% } \\
\hline & & & D35 & D45 & D35T5 & D45T5 \\
\hline 1 & $\mathrm{C}_{8} \mathrm{H}_{10}$ & p-xylene & 19.69 & 46.88 & 4.39 & 27.37 \\
\hline 2 & $\mathrm{C}_{6} \mathrm{H}_{6} \mathrm{O}$ & Phenol & & & 16.67 & \\
\hline 3 & $\mathrm{C}_{7} \mathrm{H}_{8} \mathrm{O}$ & 4-methyl-phenol & & & 13.16 & \\
\hline 4 & $\mathrm{C}_{8} \mathrm{H}_{10} \mathrm{O}$ & 3-ethyl-phenol & & & 18.42 & \\
\hline 5 & $\mathrm{C}_{8} \mathrm{H}_{10} \mathrm{O}$ & 2,4-dimethyl-phenol & & & & 2.80 \\
\hline 6 & $\mathrm{C}_{9} \mathrm{H}_{12} \mathrm{O}$ & 2-ethyl-4-methyl-phenol & & & 10.53 & \\
\hline 7 & $\mathrm{C}_{8} \mathrm{H}_{10} \mathrm{O}$ & 3,4-dimethyl-phenol & & & 3.51 & \\
\hline 8 & $\mathrm{C}_{9} \mathrm{H}_{12} \mathrm{O}$ & 2-ethyl-6-methyl-phenol & & & & 15.02 \\
\hline 9 & $\mathrm{C}_{9} \mathrm{H}_{8} \mathrm{O}$ & 2,3-dihydro-1H-inden-1-one & & & 1.75 & \\
\hline 10 & $\mathrm{C}_{6} \mathrm{H}_{10}$ & 1-methyl-cyclopentene & & & 17.54 & \\
\hline 11 & $\mathrm{C}_{10} \mathrm{H}_{12}$ & 1,2,3,4-tetrahydro-naphthalene & & 7.29 & 4.39 & 4.13 \\
\hline 12 & $\mathrm{C}_{8} \mathrm{H}_{10} \mathrm{O}_{2}$ & 2-phenoxy-ethanol & 4.06 & & & \\
\hline 13 & $\mathrm{C}_{11} \mathrm{H}_{10}$ & 1-methyl-naphthalene & 2.15 & 1.92 & & \\
\hline 14 & $\mathrm{C}_{12} \mathrm{H}_{12}$ & 2-ethenyl-naphthalene & 0.69 & & & \\
\hline 15 & $\mathrm{C}_{14} \mathrm{H}_{30}$ & Tetradecane & 3.14 & 2.36 & & \\
\hline 16 & $\mathrm{C}_{8} \mathrm{H}_{7} \mathrm{~N}$ & 1H-indole & 4.37 & & 7.02 & 9.38 \\
\hline 17 & $\mathrm{C}_{9} \mathrm{H}_{9} \mathrm{~N}$ & 6-methyl-1H-indole & & & & 12.82 \\
\hline 18 & $\mathrm{C}_{9} \mathrm{H}_{9} \mathrm{~N}$ & 2-methyl-1H-indole & & & & 5.12 \\
\hline 19 & $\mathrm{C}_{9} \mathrm{H}_{9} \mathrm{~N}$ & 3-methyl-1H-indole & & & 1.75 & \\
\hline 20 & $\mathrm{C}_{10} \mathrm{H}_{11} \mathrm{~N}$ & 5,7-dimethyl-1H-indole & & & & 6.28 \\
\hline 21 & $\mathrm{C}_{16} \mathrm{H}_{34}$ & Hexadecane & 31.80 & 17.82 & & \\
\hline 22 & $\mathrm{C}_{14} \mathrm{H}_{10}$ & Phenanthrene & 7.20 & 5.21 & & 2.07 \\
\hline 23 & $\mathrm{C}_{18} \mathrm{H}_{38}$ & Octadecane & & 18.53 & 0.88 & 7.62 \\
\hline 24 & $\mathrm{C}_{20} \mathrm{H}_{42}$ & Eicosane & 26.90 & & & 7.40 \\
\hline
\end{tabular}

Main compounds in organic fraction of aqueous products before SCWG (D35/D45) were p-xylene and long-chain aliphatic hydrocarbons (hexadecane, octadecane and eicosane), and this fraction was mostly consisting of phenolic and N-heterocyclic compounds after SCWG (D35T5/D45T5) of digested biomass. The most prominent compounds in D35T5 were phenol and substituted phenols, while p-xylene, substituted phenols, $\mathrm{N}$-heterocyclic (indole), and substituted $\mathrm{N}$-heterocyclics were mostly present in D45T5.

Digested water hyacinth with waste sludge was a complex mixture of cellulose, hemicellulose, lignin, protein, fats and inorganics that have different degradation behavior in supercritical water and provides production of numerous compounds [36]. Lignin can be degraded in hydrothermal conditions to low molecular weight products, mainly phenolic compounds that also show antioxidant properties [37]. Origin of identified $\mathrm{N}$-heterocyclic compounds can be products of hydrolysis of proteinaceous 
fraction and reaction of amino acids and sugars [38]. Anaerobic digestion process proceeds dissolution of cellulose and hemicellulose integration from lignin structure and further facilitating degradation of these fractions in SCWG. Successive application of AD with SCWG can be a potential method for production of chemical feedstock from biomasses.

\section{CONCLUSION}

Lignocellulosic biomasses can be subjected to anaerobic digestion for biogas production, but evaluation of high organic content digestate for energy production is better, instead of composting or using as fertilizer. Water hyacinth is renewable waste that does not have food value and abundantly present in nature. SCWG of anaerobically digested water hyacinth with waste sludge was investigated at different reaction temperatures and alkali catalysts in this study. Application of AD before SCWG created a pretreatment effect and facilitated degradation of digestate to products with high conversion and yield. Series application of AD with SCWG provides conversion of digested high organic content biomass to high energy carrier gaseous products $\left(\mathrm{H}_{2}\right.$ and $\left.\mathrm{CH}_{4}\right)$, and aqueous products (aliphatic hydrocarbons, phenol, substituted phenols, N-heterocyclic, substituted N-heterocyclics, and substituted benzene) that can be evaluated as chemical feedstock. This hybrid process may be applied for organic wastes to produce electricity, biomethane and biohydrogen.

\section{NOMENCLATURE}

\begin{tabular}{|c|c|}
\hline TS & Total solid (wt.\%) \\
\hline VS & Volatile solid (wt.\%) \\
\hline TC & Total carbon (wt.\%) \\
\hline $\mathrm{AD}$ & Anaerobic digestion \\
\hline SCWG & Supercritical water gasification \\
\hline TOC & Total organic carbon \\
\hline SPE & Solid-phase extraction \\
\hline CGE & Carbon gasification efficiency (wt.\%) \\
\hline CLE & Carbon liquefaction efficiency (wt.\%) \\
\hline $\mathrm{C}_{\mathrm{i}}$ & Concentration of component ' $\mathrm{i}$ ' in the gas product (vol. \%) \\
\hline $\mathrm{n}_{\mathrm{i}}$ & Number of carbon atoms of component ' $i$ ' in the gas product \\
\hline $\mathrm{m}$ & Weight of digested biomass in feed $(\mathrm{g})$ \\
\hline M & Molar mass of carbon $\left(\mathrm{g} \mathrm{mol}^{-1}\right)$ \\
\hline $\mathrm{P}$ & Pressure $(\mathrm{MPa})$ \\
\hline $\mathrm{R}$ & Universal gas constant, $8.3143 \mathrm{~J} \mathrm{~mol}^{-1} \mathrm{~K}^{-1}$ \\
\hline $\mathrm{T}$ & Temperature $(\mathrm{K})$ \\
\hline V & Volume of gas product under ambient conditions (L) \\
\hline $\bar{V}$ & Volume of aqueous product under ambient conditions (L) \\
\hline $\mathrm{w}$ & Carbon content of digested biomass (wt.\%) \\
\hline $\mathrm{TOC}_{\mathrm{aq}}$ & Total organic carbon content of the aqueous product $\left(\mathrm{g} \mathrm{L}^{-1}\right)$ \\
\hline
\end{tabular}

\section{ACKNOWLEDGMENTS}

I gratefully acknowledge for the financial support provided by Ege University, National Research Project Grants-BAP (Project No: 17MUH034). I acknowledge Prof. Dr. N. Kabay, Prof. Dr. M. Yuksel, Prof. Dr. M. Saglam and Prof. Dr. L.Ballice for valuable comments on this study. I would like to thank Assoc. Prof. Dr. A. Günes for supplying water hyacinth plants during anaerobic digestion and Mr. G. Serin for supporting mechanical work. 
Güngören Madenoğlu / Anadolu Univ. J. of Sci. and Technology A-Appl. Sci. and Eng. 19 (2) - 2018

\section{REFERENCES}

[1] Möller K, Müller T. Effects of anaerobic digestion on digestate nutrient availability and crop growth: a review. Eng Life Sci 2012; 12: 242-257.

[2] Scano EA, Asquer C, Pistis A, Ortu L, Demontis V, Cocco D. Biogas from anaerobic digestion of fruit and vegetable wastes: Experimental results on pilot-scale and preliminary performance evaluation of a full-scale power plant. Energ Convers Manage 2014; 77: 22-30.

[3] Alburquerque JA, Fuente C, Ferrer-Costa A, Carrasco L, Cegarra J, Abad M, Bernal MP. Assessment of the fertiliser potential of digestates from farm and agroindustrial residues. Biomass Bioenerg 2012; 40: 181-189.

[4] Wang H, Miao R, Yang Y, Qiao Y, Zhang Q, Li C, Huang J. Study on the catalytic gasification of alkali lignin over Ru/C nanotubes in supercritical water. J Fuel Chem Technol 2015; 43: 1195 1201.

[5] Pooya A, Sami K, Friederike S, Faraz A, Ramin F. Hydrogen production from cellulose, lignin, bark and model carbohydrates in supercritical water using nickel and ruthenium catalysts. Appl Catal B-Environ 2012; 117-118: 330-338.

[6] Ning D, Ramin A, Ajay KD, Janusz AK. Catalytic gasification of cellulose and pinewood to H2 in supercritical water. Fuel 2014; 118: 416-425.

[7] Weijin G, Binbin L, Qingyu W, Zuohua H, Liang Z. Supercritical water gasification of landfill leachate for hydrogen production in the presence and absence of alkali catalyst. Waste Manage 2017; In Press, Corrected Proof, Available online 18 December 2017 (https://doi.org/10.1016/j.wasman.2017.12.015).

[8] Sheikhdavoodi MJ, Almassi M, Ebrahimi-Nik M, Kruse A, Bahrami H. Gasification of sugarcane bagasse in supercritical water; evaluation of alkali catalysts for maximum hydrogen production. $\mathbf{J}$ Energy Inst 2015; 88: 450-458.

[9] Aaron KG, Gregory LR. Reaction rates for supercritical water gasification of xylose in a microtubular reactor. Chem Eng J 2010; 163: 10-21.

[10] Nanda S, Reddy SN, Hunter HN, Dalai AK, Kozinski JA. Supercritical water gasification of fructose as a model compound for waste fruits and vegetables. J Supercrit Fluid 2015; 104: 112121.

[11] Watanabe M, Inomata $\mathrm{H}$, Osada M, Sato T, Adschiri T, Arai K. Catalytic effects of $\mathrm{NaOH}$ and $\mathrm{ZrO} 2$ for partial oxidative gasification of $n$-hexadecane and lignin in supercritical water. Fuel 2003; 82: 545-552.

[12] Yoshida T, Matsumura Y. Gasification of cellulose, xylan, and lignin mixtures in supercritical water. Ind Eng Chem Res 2001; 40: 5469-5474.

[13] Kruse A, Meier D, Rimbrecht P, Schacht M. Gasification of pyrocatechol in supercritical water in the presence of potassium hydroxide. Ind Eng Chem Res 2000; 39: 4842-4848. 
[14] Madenoğlu TG, Yildir E, Sağlam M, Yuksel M, Ballice L. Improvement in hydrogen production from hard-shell nut residues by catalytic hydrothermal gasification. J Supercrit Fluid 2014; 95: 339-347.

[15] Muangrat R, Onwudili JA, Williams PT. Alkali-promoted hydrothermal gasification of biomass food processing waste: A parametric study. Int J Hydrogen Energ 2010; 35: 7405-7415.

[16] Onwudili JA, Lea-Langton AR, Ross AB, Williams PT. Catalytic hydrothermal gasification of algae for hydrogen production: Composition of reaction products and potential for nutrient recycling. Bioresour Technol 2013; 127: 72-80.

[17] Guan Q, Wei C, Ning P, Tian S, Gu J. Catalytic gasification of algae nannochloropsis sp. in sub/supercritical water. Procedia Environ Sci 2013; 18: 844-848.

[18] Gong M, Wang Y, Fan Y, Zhu W, Zhang H, Su Y. Polycyclic aromatic hydrocarbon formation during the gasification of sewage sludge in sub- and supercritical water: Effect of reaction parameters and reaction pathways. Waste Manage 2018; 72: 287-295.

[19] Amrullah A, Matsumura Y. Supercritical water gasification of sewage sludge in continuous reactor. Bioresour Technol 2018; 249: 276-283.

[20] Boukis N, Hauer E, Herbig S, Sauer J, Vogel F. Catalytic gasification of digestate sludge in supercritical water on the pilot plant scale. Biomass Convers Biorefin 2017; 7: 415-424.

[21] Molino A, Giordano G, Migliori M, Lauro V, Santarcangelo G, Marino T, Larocca V, Tarquini P. Process innovation via supercritical water gasification to improve the conventional plants performance in treating highly humid biomass. Waste Biomass Valori 2016; 7: 1289-1295.

[22] Sinag A, Kruse A, Rathert J. Influence of the Heating Rate and the Type of Catalyst on the Formation of Key Intermediates and on the Generation of Gases During Hydropyrolysis of Glucose in Supercritical Water in a Batch Reactor. Ind Eng Chem Res 2004; 43: 502-508.

[23] Basu P, Mettanant V. Biomass gasification in supercritical water - a review, Int J Chem React Eng, 2009; 7: Review R3.

[24] Gungoren T, Saglam M, Yuksel M, Madenoglu H, Isler R, Metecan IH. Near-critical and supercritical fluid extraction of industrial sewage sludge. Ind Eng Chem Res 2007; 46: 10511057.

[25] Kabay N. ITOB-OSB'de Enerji Bitkileriyle Atik Su Aritimi ve Aritimda Kullanilan Bitkilerin Anaerobik Fermantasyonuyla Biyogaz Üretimi (San-Tez Project), The Ministry of Science, Industry and Technology of Turkish Republic, Grant Number: STZ.0330.2013-2, 2013.

[26] Madenoğlu TG, Sağlam M, Yuksel M, Ballice L. Simultaneous effect of temperature and pressure on catalytic hydrothermal gasification of glucose. J of Supercrit Fluid 2013; 73: 151-160.

[27] Watanabe M, Aizawa Y, Iida T, Levy C, Aida TM, Inomata H. Glucose reactions within the heating period and the effect of heating rate on the reactions in hot compressed water. Carbohyd Res 2005; 340: 1931-1939. 
[28] Matsumura Y, Minowa T, Potic B, Kersten SRA, Prins W, van Swaaij WPM. Biomass gasification in near- and supercritical water: status and prospects. Biomass Bioenerg 2005; 29: 269-292.

[29] Klass, DL, Biomass for Renewable Energy, Fuels and Chemicals, Academic Press: San Diego, 1998.

[30] Elliott DC, Baker EG, The effect of catalysis on wood-gasification tar composition, Biomass 1986; 9: 195-203.

[31] Sinag A, Kruse A, Schwarzkopf V. Key compounds of the hydropyrolysis of glucose in supercritical water in the presence of $\mathrm{K}_{2} \mathrm{CO}_{3}$. Ind Eng Chem Res 2003; 42: 3516-3521.

[32] Elliott DC, Butner RS, Sealock Jr LJ. Low temperature gasification of high-moisture biomass, Res Thermochem Biomass Convers 1988; 696-710.

[33] Tsai WT, Lee MK, Chang JH, Su TY, Chang YM. Characterization of bio-oil from inductionheating pyrolysis of food-processing sewage sludges using chromatographic analysis. Bioresour Technol 2009; 100: 2650-2654.

[34] Cao C, Guo L, Yin J, Jin H, Cao W, Jia Y. Supercritical water gasification of coal with waste black liquor as inexpensive additives. Energy Fuels 2015; 29: 384-391.

[35] Noordman WH, Janssen DB. Rhamnolipid stimulates uptake of hydrophobic compounds by Pseudomonas aeruginosa. Appl Environ Microbiol 2002; 68: 4502-4508.

[36] Cao W, Cao C, Guo L, Jin H, Dargusch M, Bernhardt D, Yao X. Hydrogen production from supercritical water gasification of chicken manure. Int J Hydrogen Energ 2016; 41: 22722-22731.

[37] Kang S, Li B, Chang J, Fan J. Antioxidant abilities comparison of lignins with their hydrothermal liquefaction products. BioResources 2011; 6: 243-252.

[38] Kruse A, Maniam P, Spieler F. Influence of proteins on the hydrothermal gasification and liquefaction of biomass. 2. Model compounds. Ind Eng Chem Res 2007; 46: 87-96. 